7. Reprod. Fert. (1966) 12, 381-384

BRIEF COMMUNICATION

\title{
TRANSPORT OF OESTROGENS IN SEMEN TO THE FEMALE RAT DURING MATING AND ITS EFFECT ON FERTILITY
}

\author{
R. J. ERIGSSON AND V. F. BAKER \\ Research Laboratories, The Upjohn Company, Kalamazoo, Michigan
}

(Received 24th March 1966)

\begin{abstract}
Summary. Male rats treated with oestradiol or Carbestrol ${ }^{\oplus *}$ for 8 days were found to be incapable of impregnating normal females. Oestrogen treatment was associated with a higher incidence of headless spermatozoa recovered from vaginal smears. Hypertrophy and hyperplasia of uterine tissues along with a significant increase in uterine weights were observed on Day 1 of pregnancy. Alteration in ova transport was first observed on Day 2 when fewer cleaved ova than expected were recovered from the oviducts. No ova were recovered from the oviducts or uteri on Days 3 or 4 while the expected numbers were flushed from controls. It is concluded that such treatment leads to accumulation of oestrogens in semen, which, following coitus, is sufficient to alter events essential for conception.
\end{abstract}

Available evidence (Greenwald, 1961; Emmens \& Finn, 1962) shows that natural and synthetic oestrogens given to female rats alter ova transport and thus prevent pregnancy. Preliminary work in our laboratory showed that when oestrogens were administered to male rats which were then mated with normal females, pregnancy did not ensue. The present study was undertaken to investigate the mechanism(s) responsible for the lack of fertility following oestrogen treatment of males.

Sixty Sprague-Dawley males ( 278 to $350 \mathrm{~g}$ ) which had mated the previous night were randomly divided into two equal groups and individually caged. Pre-treatment fertility was established by killing the bred females on Day 8 of pregnancy and checking for conceptus. One group of males was injected subcutaneously with $1.0 \mathrm{mg}$ of oestradiol- $17 \beta$ (in $0.5 \mathrm{ml}$ of peanut oil) per rat daily for 8 days while controls received a like volume of oil. An oestrous female was placed with each male on the afternoon of the 8th day of treatment. On the following morning vaginal smears were checked for spermatozoa and the cages observed for vaginal plugs; spermatozoa in the vagina was the criterion used to indicate a successful mating. Bred females were housed in separate cages; males which did not copulate were re-exposed to different oestrous

* Carbestrol is a trademark of the Upjohn Company for 3-ethyl-4-( $p$-methoxyphenyl)-2-methyl3-cyclohexene-1-carboxylic acid. 
females on the following night. All female rats which mated on the 8th night and some which mated on the 9th night were autopsied on Day 8 of pregnancy to determine the number of implantation sites. The remaining females which bred on the 9th night were killed on Days 1, 2 or 3 of pregnancy (13.30 to 14.00 hours) and body and uterine weights, location and number of ova, and stages of cleavage recorded. Oviducts and/or uteri were flushed with $0.9 \%$ saline to recover the eggs. Uteri on Days 1 to 3 of pregnancy, as well as testes and epididymides were taken from treated and control animals that mated on the 9th night. Tissues were fixed in Bouin's fluid and stained with haematoxylin and eosin for histological studies. Cross-sections of uterine areas were also measured with a planimeter.

The above experiment was essentially repeated several times substituting Carbestrol (an orally active synthetic oestrogen) for oestradiol. Carbestrol at $0.0,0.5$ and $1.0 \mathrm{mg} / \mathrm{rat}$ doses was given by gavage in sterile water which contained $0.25 \%$ methyl cellulose. The results, when pertinent, will be incorporated with the oestradiol data or summarized in Table form.

TABLE 1

BODY AND UTERINE WEIGHTS ON DAYS 1, 2 AND 3 OF PREGNANGY FROM FEMALES MATED WITH OESTRADIOL-TREATED OR CONTROL MALE RATS

\begin{tabular}{|c|c|c|c|c|}
\hline \multirow[b]{2}{*}{$\begin{array}{c}\text { Day of } \\
\text { pregnancy }\end{array}$} & \multicolumn{2}{|c|}{ Oestradiol } & \multicolumn{2}{|c|}{ Control } \\
\hline & $\begin{array}{c}\text { Body } \\
\text { weight } \\
(\mathrm{g})\end{array}$ & $\begin{array}{c}\text { Uterine } \\
\text { weight } \\
(\mathrm{mg})\end{array}$ & $\begin{array}{c}\text { Body } \\
\text { weight } \\
(\mathrm{g})\end{array}$ & $\begin{array}{c}\text { Uterine } \\
\text { weight } \\
(m g)\end{array}$ \\
\hline 1 & $\begin{array}{l}220 \\
196 \\
181\end{array}$ & $\begin{array}{l}521 \\
456 \\
479\end{array}$ & $\begin{array}{l}200 \\
196 \\
203\end{array}$ & $\begin{array}{l}315 \\
331 \\
329\end{array}$ \\
\hline Average & 199 & $485^{*}$ & 200 & 325 \\
\hline 2 & $\begin{array}{l}230 \\
224 \\
198\end{array}$ & $\begin{array}{l}320 \\
315 \\
308\end{array}$ & $\begin{array}{l}214 \\
212 \\
222\end{array}$ & $\begin{array}{l}350 \\
240 \\
275\end{array}$ \\
\hline Average & 217 & 314 & 216 & 288 \\
\hline 3 & $\begin{array}{l}208 \\
206 \\
220\end{array}$ & $\begin{array}{l}360 \\
358 \\
270\end{array}$ & $\begin{array}{l}208 \\
200\end{array}$ & $\begin{array}{l}250 \\
238\end{array}$ \\
\hline Average & 211 & 329 & 204 & 244 \\
\hline
\end{tabular}

* Significantly $(P<0.01)$ greater than control uterine weights.

Pre-treatment conception rate was $90.0 \%$ (twenty-seven out of thirty) in the oestradiol-treated group and $80.0 \%$ (twenty-four out of thirty) in the control group. The average number of conceptus for the fifty-one pregnant females was 12.4. Seven treated and sixteen control males mated on the 8th night and thirteen and eight, respectively, mated on the 9th night. Ejaculated spermatozoa from oestradiol- and Carbestrol-treated males found in vaginal smears were, for the most part, headless. Sometimes dead spermatozoa became decapitated 
but heads and tails (separated) could be seen floating freely in the smear. This was not the case with the treated males, as many more tails than heads could be identified. However, epididymal spermatozoa taken on the 10th day of the experiment were not morphologically different from those of the controls. Cupps \& Briggs (1965) were able to bring about epididymal spermatozoa abnormalities in bulls by extended treatment with oestrogens. The shorter treatment in rats may have physiologically altered spermatozoa; although this manifestation did not become evident until the spermatozoa were exposed to the environment of the female tract, at which time they separate at the weakest link-the neck.

Body and uterine weights from rats killed on Days 1, 2 and 3 of pregnancy are given in Table 1. The much heavier uteri found on Day 1 of pregnancy in

TABLE 2

NUMBER, LOCATION AND STAGE OF CLEAVAGE OF OVA FLUSHED FROM FEMALES BRED TO OESTRADIOL- AND CARBESTROL-TREATED AND CONTROL MALE RATS

\begin{tabular}{|c|c|c|c|c|c|}
\hline $\begin{array}{c}\text { Day of } \\
\text { pregnancy }\end{array}$ & Treatment & $\begin{array}{l}\text { No. of } \\
\text { Females }\end{array}$ & $\begin{array}{c}\text { Average } \mathcal{N} \text {. } \\
\text { of ova }\end{array}$ & $\begin{array}{l}\text { Location } \\
\text { of ova }\end{array}$ & $\begin{array}{l}\text { Stages of } \\
\text { cleavage }\end{array}$ \\
\hline 1 & $\begin{array}{l}\text { Oestradiol } \\
\text { Carbestrol } \\
\text { Control }\end{array}$ & $\begin{array}{l}3 \\
2 \\
4\end{array}$ & $\begin{array}{l}12 \cdot 7 \\
13 \cdot 5 \\
12 \cdot 7\end{array}$ & $\begin{array}{l}\text { Ampulla } \\
\text { Ampulla } \\
\text { Ampulla }\end{array}$ & $\begin{array}{l}1 \text {-cell* } \\
1 \text {-cell } \\
1 \text {-cell* }\end{array}$ \\
\hline 2 & $\begin{array}{l}\text { Oestradiol } \\
\text { Control }\end{array}$ & $\begin{array}{l}3 \\
3\end{array}$ & $\begin{array}{r}4 \cdot 3 \\
10 \cdot 7\end{array}$ & $\begin{array}{l}\text { Ampulla and } \\
\text { oviduct } \\
\text { Ampulla and } \\
\text { oviduct }\end{array}$ & $\begin{array}{l}\text { 1- and 2-cell* } \\
1 \text { - and 2-cell* }\end{array}$ \\
\hline 3 & $\begin{array}{l}\text { Oestradiol } \\
\text { Carbestrol } \\
\text { Control }\end{array}$ & $\begin{array}{l}3 \\
2 \\
3\end{array}$ & $\begin{array}{c}0 \\
0 \\
10 \cdot 3\end{array}$ & $\begin{array}{r}- \\
\text { Oviduct }\end{array}$ & 2- and $\overline{-}$ \\
\hline 4 & $\begin{array}{l}\text { Carbestrol } \\
\text { Control }\end{array}$ & $\begin{array}{l}4 \\
2\end{array}$ & $\begin{array}{c}0 \\
10 \cdot 0\end{array}$ & Oviduct & 8-cell \\
\hline
\end{tabular}

* Spermatozoa were attached to some of the ova.

in females bred to treated males is a good indication that oestrogen had been deposited in the female reproductive tract. An increase in rat uterine weights has been used as a biological assay for oestrogens for many years (Lauson, Heller, Golden \& Sevringhaus, 1939) Ova from all females were in the ampullar region of the oviduct on Day 1 of pregnancy (Table 2). Spermatozoa from oestradiol-treated and control males were seen attached to ova; it is not known, however, if the spermatozoa from treated males are normal. Alteration of 2-cell ova transport appears to start on Day 2, in females bred to treated males, as the recovery rate of such eggs was much reduced (Table 2). On Days 3 and 4 ova from controls were in the 2- to 8-cell stages of cleavage and located in the posterior region of the oviduct. No ova were recovered from the oviducts or uteri of females bred to oestradiol- or Carbestrol-treated males, although they had ovulated. The results are summarized in Table 2. These results support the hypothesis that sufficient oestrogen was deposited in the female reproductive tract during ejaculation to cause rapid transport of ova out of the oviduct and 
uterus. Similar results were obtained in our laboratory by treating rats intravaginally with oestrone on Day 1 of pregnancy (unpublished data).

Fifty-one per cent of the Carbestrol-treated, $67 \%$ of the oestradiol-treated and $87 \%$ of the control males mated when exposed to oestrous females. Oestrogen treatment reduced the number of vaginal plugs produced from $100 \%$ in controls to $41 \%$ in Carbestrol- and $45 \%$ in oestradiol-treated males. Autopsy of females bred to males treated with either drug revealed that none of them were pregnant. All females which mated with control males were pregnant and had an average of 11.8 implantations sites.

Histological studies of testes from oestradiol-treated rats revealed seminiferous tubules in all stages of spermatogenesis. However, the lumina of the epididymides contained numerous immature germ cells in addition to spermatozoa. This observation was not seen in epididymides taken from control rats. Hypertrophy and hyperplasia of both myometrium and endometrium were seen in uterine sections taken from females which received the semen containing oestrogen. These marked histological differences were only apparent on Day 1 of pregnancy when compared to control females.

Appreciation is expressed to Dr R. L. Johnston for doing planimeter measurements of areas of the uterus and also for help in reading uterine slides.

\section{REFERENCES}

CuPPs, P. T. \& BRIGGs, J. R. (1965) Changes in the epididymis associated with morphological changes in the spermatozoa. F. Dairy Sci. 48, 1241.

Emmens, G. W. \& FinN, G. A. (1962) Local and parenteral action of oestrogens and anti-oestrogens on early pregnancy in the rat and mouse. 7 . Reprod. Fert. 3, 239.

Greenwald, G. S. (1961) The anti-fertility effects in pregnant rats of a single injection of estradiol cyclopentylpropionate. Endocrinology, 69, 1068.

Lauson, H. D., Heller, C. G., Golden, J. B. \& Sevringhaus, E. L. (1939) The immature rat uterus in the assay of estrogenic substances, and a comparison of estradiol, estrone and estriol. Endocrinology, 24, 35. 